ORIGINAL ARTICLE

\title{
ANALISIS POTENSI EKOSISTEM TERUMBU KARANG UNTUK KESESUAIAN LOKASI WISATA SELAM, PANTAI DATO KABUPATEN MAJENE
}

Andi Arham Atjo*a, Rezki Fitriah ${ }^{a}$, Rahmi Nur ${ }^{b}$

aUniversitas Sulawesi Barat,

${ }^{b}$ Universitas Hasanuddin

(C) The author (s) and Siganus: Journal of Fisheries and Marine Science/Fakultas Peternakan dan Perikanan

*Informasi Artikel

Received : 26 Juli 2019

Accepted: 26 Agustus 2019

*Corresponding Author

Andi Arham Atjo

Program Studi Akuakultur Universitas Sulawesi Barat. Email: arhamandi@unsulbar.ac.id

How to cite:

Atjo A.A., Fitriah F., \& Nur R., 2019. Analisis Potensi Ekosistem Terumbu Karang Untuk Kesesuaian Lokasi Wisata Selam, Pantai Dato Kabupaten Majene. Siganus: Journal of Fisheries and Marine Science. 2 (1). 1-9

\section{A B S T R A K}

Penelitian ini bertujuan untuk mengetahui potensi dan kondisi Pantai Dato sebagai objek wisata selam yang ditinjau berdasarkan aspek biofisik. Metode Penelitian meliputi Waktu dan tempat yaitu pada bulan Mei-April 2019 Bertempat di Perairan Pantai Dato, Perisiapan Alat dan Bahan, Prosedur Lapangan, Analisis data, dan Pelaporan. kawasan Pantai Dato menunjukkan untuk kegiatan wisata selam kedalaman 10 meter pada Stasiun IV, VI dan VII termasuk kategori cukup sesuai (S2), faktor yang masih minim dan menjadi pembatas yakni parameter tutupan karang, jumlah lifeform karang dan jenis ikan karang. Sedangkan pada Stasiun V termasuk kategori sangat sesuai (S1) namun masih ada parameter yang memiliki nilai dibawah standar kesesuaian kawasan untuk kategori sangat sesuai (S1) yakni parameter jumlah Lifeform karang dan jenis ikan karang.

Kata Kunci: Ekosistem, Karang, Wisata, Selam, Dato

\section{A B S T R A C T}

The present study aimed to determine the potential and condition of Dato Beach as a dive tourism object based on biophysical aspects. This study was conducted from May to April 2019 located in the waters of Dato Beach. Prior of study, the preparation of materials and equipments and manual field procedures were prepared including data analysis. The results showed that Dato Beach potentially as diving spot for tourism, especially in 10 meters depth at Station IV, VI and VII (S2), the coral cover, the number of coral lifeforms and types of coral fish were several limiting factors. While at Station $\mathrm{V}$ was included as very suitable spot category (S1). Nonetheless, several values was below standard category (S1), particularly, the number of coral lifeforms and types of reef fish

Keywords : ecosystem, reef, tourism, diving, Dato 


\section{Pendahuluan}

Wilayah pesisir merupakan daerah pertemuan antara wilayah daratan dengan karakteristik daratannya dan wilayah lautan dengan karateristik lautannya dan membawa dampak yang cukup signifikan terhadap pembentukan karakteristik wilayahnya sendiri yang khas. Kekhasan ini tidak hanya berlaku pada karakteristik sumberdaya alamnya saja, melainkan juga berdampak pada karakteristik sumberdaya manusia yang ada disekitarnya (Dahuri et al., 2004).

Berbagai ekosistem yang ada memberikan kekhasan tersediri pada wilayah pesisir. Sebutlah misalnya ekosistem yang bersifat alami seperti terumbu karang dan pantai berpasir, sumberdaya yang dapat pulih seperti berbagai jenis ikan dan lamun dan juga sumberdaya yang tidak dapat pulih seperti minyak dan gas. Di samping itu, beberapa lokasi-lokasi dalam wilayah pesisir saat ini banyak dijadikan sebagai tujuan wisata baik wisata pantai maupun wisata bahari sebab lokasi-lokasi tersebut menawan dan menarik untuk dinikmati.

Pengembangan kepariwisataan bahari pada hakekatnya merupakan upaya untuk mengembangkan dan memanfaatkan obyek wisata dan daya tarik wisata bahari yang terdapat di seluruh wilayah Indonesia, yang terwujud antara lain dalam bentuk kekayaan alam yang indah, keragaman berbagai flora dan fauna. Disisi lain, sumberdaya alam yang ada di wilayah pesisir dan lautan telah pula dimanfaatkan untuk pemenuhan kebutuhan manusia, baik sebagai mata pencaharian, sumber pangan, mineral, energi, devisa, kawasan pariwisata dan lain-lain.

Besarnya potensi yang dimiliki wilayah pesisir menyebabkan pengembangan kawasan ini semakin giat dilakukan. Tren yang sedang marak diekspos di media massa maupun media cetak saat ini adalah wisata pantai dan wisata bahari terutama wisata bawah laut, sehingga minat untuk berwisata baik yang dilakukan wisatawan lokal maupun mancanegara semakin meningkat. Hal ini sudah barang tentu akan memberikan dampak terhadap kerusakan ekosistem dan sumberdaya alam yang besar di wilayah ini.

Sumberdaya alam yang beranekaragam dari aspek fisik dan hayati wilayah pesisir merupakan potensi yang dapat dikembangkan untuk kawasan pariwisata. Sayangnya potensi tersebut belum dimanfaatkan secara optimal, sementara itu potensi pariwisata dapat menaikkan devisa negara. Hingga saat ini, di Indonesia hanya dikenal beberapa resort dan pantai yang telah memiliki nama dan dikenal dalam wisata bahari (Tuwo, 2011).

Sebagai gambaran, pada tahun 1992 pengembangan bidang pariwisata telah mampu menghasilkan devisa bagi Negara sekitar US $\$ 2.533$ juta. Devisa dari pariwisata ini posisinya menduduki urutan kelima setelah minyak, gas, tekstil dan kayu. Padahal tahun 1985 yaitu enam tahun sebelumnya, penghasilan devisa Indonesia dari pariwisata menduduki tempat ke tujuh.

Beberapa daerah pesisir yang memiliki kawasan yang dapat dijadikan sebagai potensi objek wisata adalah salah satunya wilayah pesisir Kabupaten Majene Propinsi Sulawesi Barat.Kabupaten Majene dengan panjang garis pantai $\pm 112 \mathrm{~km}$ teridentifikasi banyak memiliki lokasi-lokasi untuk dapat dijadikan sebagai tujuan wisata diantaranya adalah Pantai Dato.Pantai Dato yang beradadi Kecamatan Banggae Timur terletak di Dusun Pangale Kelurahan Baurung Kota Majene memiliki keunikan selain memiliki keindahan pantai tropis juga terbilang masih alami dan terjaga dengan baik.Pantai ini terbagi dua bagian yaitu pantai berpasir dan pantai beralaskan terumbu karang.Keberadaan pantai yang berkarang dan menjorok ke laut menambah daya pesonanya.

Panorama alam pantai di Pantai Dato Majene memang menawan dan memanjakan mata.Ditambah lagi udara pesisir yang sejuk yang dapat memberi efek rileks. Pemandangan dan topografi yang unik di pantai ini juga menjadi kelebihan tersendiri berupa hamparan pasir, di sisi lain terdapat pantai yang penuh denganpecahan batu karang. Pemandangan menarik lainnya adalah konturtebing berbatu yang memiliki bentuk yang unik karena dihempas ombak secara terus-menerus selama ratusan tahun.

Pantai Dato merupakan kawasan pengembangan wisata yang dikelola oleh Dinas Olahraga, Kebudayaan dan Pariwisata Kabupaten Majene. Pantai Dato merupakan pantai tropis unik dan salah satu pantai andalan yang terletak di Dusun Pangale, Kelurahan Baurung, Kecamatan Banggae Timur, Kabupaten Majene, Provinsi Sulawesi Barat yang belum dimanfaatkan secara optimal.

Saat ini permasalahan di Pantai Dato yang nampak adalah belum adanya hasil kajian tentang aspek biofisik yang dapat dijadikan acuan bagi pengembangan daerah wisata Pantai Dato Kabupaten Majene. Olehnya itu perlu dilakukan 
penelitian tentang Analisis Potensi Biofisik dan Kesesuaian Lokasi Wisata, Pantai Dato Kabupaten Majene sebagai awal untuk mengurai permasalahan dan menguak potensi sumberdaya dalam konteks pariwisata berkelanjutan.

\section{Metodologi Penelitian}

\section{Tempat dan Waktu Penelitian}

Penelitian dilakukan di Pantai Dato Kabupaten Majene Provensi Sulawesi Barat. Pantai Dato yang menjadi objek penelitian terletak di Dusun Pangale, Kelurahan Baurung, Kecamatan Banggae Timur, Kabupaten Majene dengan titik koordinat 030 39'19,13" - 03 33' 42,14" LS dan 1180 59' 6,22" $118^{\circ} 58^{\prime}$ 43,16" BT. Penelitian dilakukan pada bulan Mei-April 2019. Studi pendahuluan dilakukan pada tanggal 02 Januari 2019 untuk memperoleh informasi awal tentang daerah dan objek penelitian melalui observasi langsung.

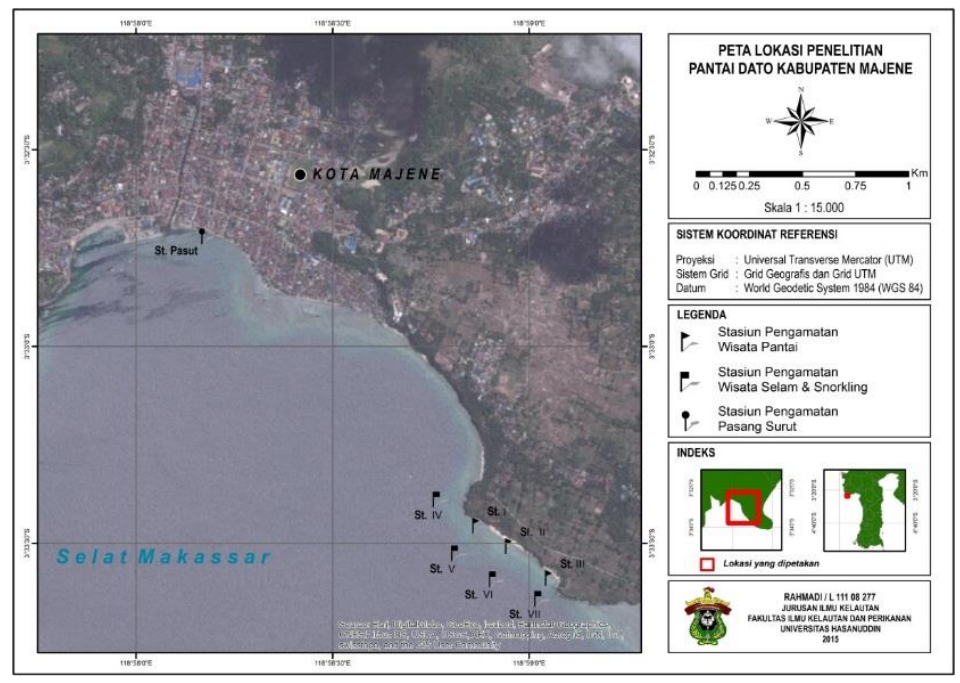

Gambar 1. Peta Lokasi Penelitian.

Tabel 1. Lokasi Pengamatan Ekosistem Terumbu Karang Kawasan Pantai Dato.

\begin{tabular}{|c|c|c|}
\hline \multirow{2}{*}{ Stasiun } & \multicolumn{2}{|c|}{ Koordinat } \\
\cline { 2 - 3 } & Lintang & Bujur \\
\hline I & $03^{\circ} 33^{\prime} 22,76 " \mathrm{~S}$ & $118^{\circ} 58^{\prime} 46,30^{\prime \prime} \mathrm{E}$ \\
\hline II & $03^{\circ} 33^{\prime} 31,55^{\prime \prime} \mathrm{S}$ & $118^{\circ} 58^{\prime} 49,34^{\prime \prime} \mathrm{E}$ \\
\hline III & $03^{\circ} 33^{\prime} 34,02^{\prime \prime} \mathrm{S}$ & $118^{\circ} 58^{\prime} 57,03^{\prime \prime} \mathrm{E}$ \\
\hline IV & $03^{\circ} 33^{\prime} 38,50^{\prime \prime} \mathrm{S}$ & $118^{\circ} 59^{\prime} 02,03^{\prime \prime} \mathrm{E}$ \\
\hline
\end{tabular}

\section{Alat dan Bahan}

Alat dan bahan yang digunakan dalam penelitian ini berupa: (1) perahu motor untuk mobilitas diperairan,
(2) Global Positioning System (GPS) digunakan untuk menentukan titik koordinat, (3) kompas untuk menentukan arah mata angin, (4) alat selam dasar (fins, masker, snorkel) dan SCUBA set (SCUBA tank, $B C D$, regulator) digunakan untuk pendataan ekosistem terumbu karang, (5) secchi disk untuk mengukur kecerahan, (6) meteran gulung digunakan sebagai transek garis pendataan karang, (7) layanglayang arus dan stopwatch digunakan untuk mengukur kecepatan arus, (8) tiang skala dua buah untuk mengukur tinggi gelombang dan pasang surut perairan, (9) kamera underwater untuk dokumentasi kegiatan, (10) underwater paper/sabak untuk pendataan dibawah air dan kertas A4.

Sedangkan bahan yang akan digunakan adalah beberapa literatur serta data sekunder dari beberapa laporan dan dokumen yang berkaitan dengan penelitian dicantumkan sebagai sumber informasi.

\section{Metode Pengumpulan Data}

\section{Studi Pendahuluan}

Pada tahap ini dilakukan studi literatur, pengurusan administrasi penelitian dan pengumpulan data sekunder yang ada hubungannya dengan objek penelitian seperti Peta Tematik, Peta Lingkungan Pantai Indonesia serta mempersiapkan alat/instrument yang digunakan pada saat melakukan pengukuran di lapangan.

\section{Survei Awal}

Tahapan ini dilakukan untuk mengetahui gambaran awal tentang kondisi lokasi penelitian. Gambaran awal mengenai kenampakan lokasi yang secara visual mendukung sebagai lokasi wisata pantai, selam dan snorkeling, seperti: luas kawasan pantai, hamparan terumbu karang, kemiringan pantai, keindahan panorama pantai, dan lokasi yang berada untuk kepentingan penentuan titik stasiun.

\section{Penentuan Titik Stasiun}

Penentuan stasiun penelitian dilakukan berdasarkan keberadaan dan kondisi pantai pada wilayah yang dianggap mewakili lokasi wisata tersebut, maka ditentukanlah 4 Stasiun peruntukan kawasan wisata selam. Penentuan stasiun sejajar dengan garis pantai dengan menggunakan GPS (Global Positioning System), dangan data penutupan karang hidup dan identifikasi jenis ikan karang yang berdasarkan pada dua kedalaman antara 3-5 meter dan antara 7-10 meter ditiap Stasiunnya.Dua kedalaman tersebut dianggap mewakili kondisi terumbu karang karena 
biasanya karang tumbuh dengan baik dan keragaman jenis karang tinggi pada kedalaman tersebut.

\section{Pengambilan Data Lapangan}

Pengukuran data di lapangan dilakukan dengan pengambilan beberapa parameter yang diukur adalah sebagai berikut:

\section{Tutupan Komunitas Karang}

Penentuan kondisi terumbu karang di lapangan dilakukan pengambilan data penutupan karang dengan menggunakan metode LIT (Line Intercept Transect) untuk mengidentifikasi bentuk pertumbuhan karang. Metode LIT dalam penelitian ini menggunakan transek garis 50 meter yang dibentangkan disetiap stasiun yang telah ditentukan. Transek dipasang sejajar garis pantai dengan mengikuti Ikan Karang

Pendataan kelimpahan ikan dilakukan bersamaan dengan pendataan jenis pertumbuhan karang.Jenis ikan yang dihitung dibatasi oleh panjang transek yang telah dibentangkan sebelumnya pada pendataan karang.Identifikasi Ikan karang yaitu menggunakan metode sensus langsung (visual sensus method) (English et al., 1997). Metode sensuslangsung dengan hanya mendata ikan yang berada 2,5 meter disebelah kiri, kanan, dan 5 meter diatas dari posisi transek terbentang.

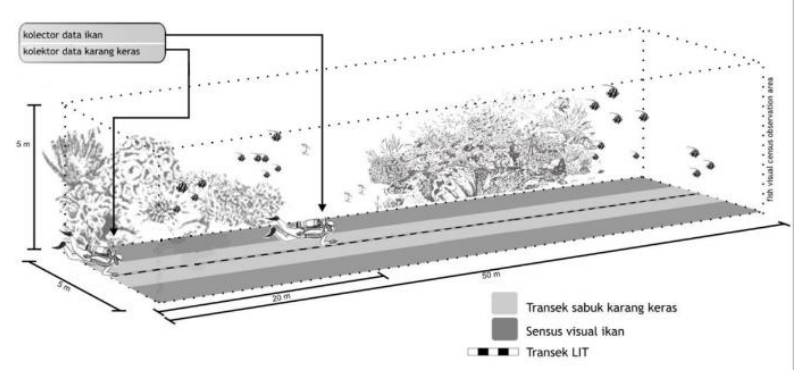

Gambar 2. Metode Visual Sensus yang dipakai dalam pengamatan (Yusri, 2009) dan hasil modifikasi (2014).

Data hasil Identifikasi ikan karang dikelompokkan berdasarkan 3 kategori indikator, target dan mayor dengan menggunakan buku identifikasi merujuk pada Panduan Dasar Untuk Pengenalan Ikan Karang Secara Visual Indonesia, March, Jakarta, 2004.

\section{Kedalaman Perairan}

Pengukuran kedalaman pada Stasiun I, II, III dan IV untuk kegiatan wisata snorkeling dan selam menggunakan batu duga dengan menimalisasi pengaruh arus terhadap sudut vertikal kedalaman perairan.

\section{Tipe Pantai dan Material Dasar Perairan}

Penentuan tipe pantai dan material dasar perairan dilakukan berdasarkan pengamatan visual atau melihat langsung material substrat penyusunnya.

\section{Lebar Hamparan Pantai dan Terumbu Karang}

Pengukuran lebar hamparan pantai dilakukan dengan menggunakan roll meter, yaitu diukur jarak antara vegetasi terakhir yang ada dipantai dengan batas pasang tertinggi.Sedangkan untuk pengukuran lebar hamparan terumbu karang dilakukan dengan melihat intepretasi citra pada perairan, agar didapatkan gambaran sebaran karang pada daerah terumbu, sehingga dapat dihitung hasil lebar dari hamparan karang.Lebar hamparan karang dihitung jarak karang yang berada paling dekat dengan bibir pantai sampai tutupan karang paling jauh mengarah keluar.

\section{Kemiringan Pantai}

Untuk mengetahui kelerengan suatu areal maka terlebih dahulu diukur kemiringan dengan menggunakan busur derajat (dilengkapi dengan bandul) dan roll meter.Langkah awal yaitu ditentukan Stasiun yang akan diukur yaitu sebanyak tiga Stastiun pengamatan. Tiang pancang $\pm 1 \mathrm{~m}$ ditancapkan untuk menjadi patokan kemiringan pada masing-masing ujung dari titik pengukuran.Kemudian tali dibentangkan sepanjang area pengukuran dengan berpatokan pada ujung tiang pancang, kemudian busur derajat diletakkan di pinggiran tali, selanjutnya dilihat dan dicatat skala yang ditunjukkan pada busur dengan mengacu pada tabel hubungan antara topografi pantai dengan kemiringan pantai sebai berikut :

Tabel 2. Hubungan Antara Topografi Pantai Dengan Kemiringan (Yulianda, 2007dalam Armos, 2013)

\begin{tabular}{|c|c|c|c|c|}
\hline Parameter & \multicolumn{4}{|c|}{ Nilai sebutan } \\
\hline Kemiringan $\left({ }^{\circ}\right)$ & $<10$ & $10-25$ & $>25-45$ & $>45$ \\
\hline Topografi Pantai & Datar & Landai & Curam & Terjal \\
\hline
\end{tabular}

Selanjutnya dalam hal penentuan batas aman renang pengukuran kelandaian pantai dari darat ke perairan yaitu dengan cara diukur kedalaman perairan sampai batas $\pm 150 \mathrm{~cm}$ pada saat pasang dan 
pada saat surut dengan menggunakan roll meter. Batas kedalaman didasari pada batas toleransi aman berenang yaitu ukuran sampai $\pm 150 \mathrm{~cm}$ yang merupakan batas tinggi leher orang dewasa Indonesia.

\section{Kecepatan Arus}

Pengukuran arah dan kecepatan arus dilakukan dengan menggunakan layang-layang arus (drift float) yakni dengan menghitung selang waktu $(\Delta \mathrm{T})$ yang dibutuhkan pelampung untuk menempuh suatu jarak $(\Delta \mathrm{X})$ tertentu, sedangkan untuk pengukuran arah arus ditentukan dengan menggunakan kompas yaitu dengan cara melihat arah dari layang-layang arus. Pengukuran arah dan kecepatan arus dilakukan pada setiap Stasiun.

\section{Kecerahan Perairan}

Pengukuran kecerahan dilakukan dengan menggunakan secchi disk yangdiikat dengan tali kemudian diturunkan perlahan-lahan ke dalam perairan hingga tidak tampak, yakni warna putih pada secchi disk tidak lagi terlihat. Kemudian diukur panjangnya dengan meteran, akan tetapi, sebelumnya diukur kedalaman perairan pada lokasi pengamatan.Setelah itu, secara perlahan tarik secchi disk keatas hingga warna putih pada secchi disk tersebut kembali terlihat lalu diukur juga berapa panjangnya, ini adalah batas tampak. Setelah nilai batas tidak tampak dan batas tampak telah didapat, maka dijumlah kedua nilai tersebut lalu dibagi kedalaman perairan pengamatan dikali $100 \%$.Pengukuran kecerahan perairan dilakukan pada setiap stasiun.

\section{Gelombang Laut}

Pengukuran tinggi, periode dan arah ombak di lakukan dengan menggunakan tiang skala, stopwatch, kompas dan alat tulis menulis. Pengukuran tinggi ombak dilakukan dengan cara membaca pergerakan naik (puncak) dan turun (lembah) permukaan air laut pada tiang skala yang telah dipasang sebelumnya sebelum ombak pecah, pembacaan puncak dan lembah masing-masing dilakukan sebanyak 51 kali pada tiap stasiun. Sedangkan periode gelombang diukur dengan mencatat waktu yang diperlukan oleh gelombang selama puncak dan lembah dengan menggunakan stopwatch dalam melewati

\section{Pasang Surut}

Pengukuran pasang surut dimulai dengan penentuan lokasi yang representatif untuk pemasangan tiang skala dan dicatat posisinya dengan GPS.Tiang skala dipasang pada daerah yang tetap tergenang air pada saat surut. Pengamatandilakukan selama 39 jam dengan interval waktu pengamatan 1 (satu) jam. Hal ini selain dimaksudkan untuk mengetahui tipe pasang surut juga untuk mengetahui mean sea level (MSL) lokasi penelitian yang nantinya digunakan untuk mengoreksi kedalaman perairan.

\section{Analisa Data}

Analisis data yang digunakan yakni analisis data secara deskriptif.Data yang diperoleh dihitung dan diolah, kemudian disajikan dalam bentuk grafik dan tabel.Data yang diperoleh baik data lapangan (primer) maupun data pendukung (sekunder) selanjutnya dijadikan bahan untuk interpretasi peruntukan melalui uji skoring.

\section{Potensi Biofisik}

Tutupan Komunitas Karang

Persentase penutupan komunitas terumbu karangdihitung dengan menggunakan rumus sebagai berikut (Englishet al., 1997):

$$
\text { Persen penutupan }(\%)=\frac{\text { Panjang Total Kelompok Karang }}{\text { Panjang Transek }} \times 100
$$

Dengan demikian, dapat diketahui tingkat kerusakan berdasarkan persentase penutupan komunitas karang hidup. Kriteria persentase tutupan komunitas karang yang digunakan, berdasarkan Keputusan Menteri Negara Lingkungan Hidup No. 4 Tahun 2001 tentang kriteria baku kerusakan terumbu karang dengan kategori sebagai berikut:

$$
\begin{array}{lll}
\text { 1. } & \text { Kategori rusak } & : 0-24,9 \% ; \\
\text { 2. Kategori sedang } & : 25-49,9 \% ; \\
\text { 3. Kategori Baik } & : 50-74,9 \% ; \\
\text { 4. Kategori baik sekali } & : 75-100 \% .
\end{array}
$$

Pengambilan data kondisi terumbu karang dan ikan karang dilakukan pada kedalaman antara 3-5 meter dan antara 7- 10 meter.Dua kedalaman tersebut dianggap mewakili kondisi terumbu karang karena biasanya karang tumbuh dengan baik dan keragaman jenis karang tinggi pada kedalaman tersebut.

\section{Kelimpahan Ikan}


Kelimpahan ikan karang merupakan, jumlah ikan terumbu yang ditemukan pada suatu stasiun pengamatan persatuan luas transek pengamatan. Kelimpahan ikan dapat dihitung dengan rumus (Odum, 1971dalam Yusri, 2009):

$$
X i=\frac{n i}{A}
$$

Dimana:

$$
\begin{aligned}
& \mathrm{Xi}=\text { Kelimpahan individu ikan kategori ke-i (ind/ha) } \\
& \mathrm{ni} \quad=\text { Jumlah individu ikan kategori ke-i yang diperoleh tiap stas } \\
& \mathrm{A} \quad=\text { Luas daerah pengamatan }\left(\mathrm{m}^{2}\right) \\
& 0,025=\text { Konversi dari } 50 \mathrm{~m}^{2} \text { ke ha }
\end{aligned}
$$

\section{Kedalaman Perairan}

Pengukuran kedalaman dikoreksi dengan hasil pengukuran pasang surut sehingga dapat diketahui kedalaman sesungguhnya terhadap referensi Duduk

\begin{tabular}{|c|c|c|c|c|}
\hline No & Parameter & Bobot & Kelas & Skor \\
\hline \multirow{4}{*}{1} & \multirow{4}{*}{ Kecerahan Perairan (\%) } & \multirow{4}{*}{5} & 80 & 3 \\
\hline & & & $\geq 50-<80$ & 2 \\
\hline & & & $\geq 20-<50$ & 1 \\
\hline & & & $<20$ & 0 \\
\hline \multirow{4}{*}{2} & \multirow{4}{*}{$\begin{array}{l}\text { Tutupan Komunitas Karang } \\
\text { Hidup (\%) }\end{array}$} & \multirow{4}{*}{5} & $>75$ & 3 \\
\hline & & & $>50-\leq 75$ & 2 \\
\hline & & & $>25-\leq 50$ & 1 \\
\hline & & & $\leq 25$ & 0 \\
\hline \multirow{4}{*}{3} & \multirow{4}{*}{ Jenis Lifeform Karang } & \multirow{4}{*}{3} & $>12$ & 3 \\
\hline & & & $>7-\leq 12$ & 2 \\
\hline & & & $\geq 4-\leq 7$ & 1 \\
\hline & & & $>4$ & 0 \\
\hline \multirow{4}{*}{4} & \multirow{4}{*}{ Jenis Ikan Karang } & \multirow{4}{*}{3} & $>100$ & 3 \\
\hline & & & $250-\leq 100$ & 2 \\
\hline & & & $\geq 20-<50$ & 1 \\
\hline & & & $<20$ & 0 \\
\hline \multirow{4}{*}{5} & \multirow{4}{*}{ Kecepatan Arus $(\mathrm{cm} / \mathrm{s})$} & \multirow{4}{*}{1} & $<15$ & 3 \\
\hline & & & $>15-\leq 30$ & 2 \\
\hline & & & $>30-\leq 50$ & 1 \\
\hline & & & $>50$ & 0 \\
\hline \multirow{4}{*}{6} & \multirow{4}{*}{$\begin{array}{l}\text { Kedalaman Terumbu Karang } \\
\text { (meter) }\end{array}$} & \multirow{4}{*}{1} & $(6-15)$ & 3 \\
\hline & & & $>15-20$ & 2 \\
\hline & & & $>20-30$ & 1 \\
\hline & & & $>30$ dan $<1$ & 0 \\
\hline
\end{tabular}
Tengah Sementara (Armos, 2013):

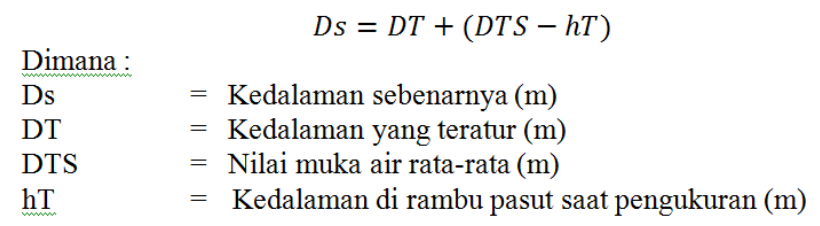

Tabel 3. Matriks Kesesuaian Wisata Selam (Yulianda, 2007).

\section{Kecepatan Arus}

Kecepatan arus dihitung dengan menggunakan persamaan Kreyzig dalam Rafy (2003) sebagai berikut

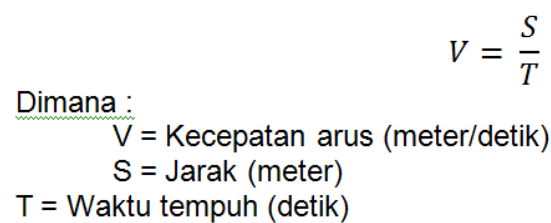

\section{Analisis Kesesuaian Wisata Selam}

Analisis kesesuaian wisata menggunakan matriks kesesuaian disusun berdasarkan kepentingan setiap parameter untuk mendukung kegiatan pada daerah tersebut. Matriks kesesuaian untuk Wisata Selam dapat dilihat pada tabel 5 .

Matriks tersebut digunakan sebagai acuan untuk menggunakan indeks kesesuaian wisata dalam penentuan potensi suatu lokasi dalam penentuan kawasan wisata. Rumus yang digunakan untuk kesesuaian wisata menurut Yulianda (2007) adalah sebagai berikut:

$$
\begin{array}{ll} 
& \text { IKW }=\sum\left(\frac{\mathrm{Ni}}{\text { N maks }}\right) \times 100 \\
\text { Dimana: } & =\text { Indeks Kesesuaian Wisata }(\%) \\
\text { IKW } & =\text { Nilai Parameter Ke-l (bobot } \times \text { skor) } \\
\mathrm{Ni} & =\text { Nilai Maksimum Suatu kategori Wisata }
\end{array}
$$

Dari hasi perhitungan indeks kesesuaian wisata ini maka dapat dilihat kelas kesesuaian kawasannya (Yulianda, 2007) dengan kategori sebagai berikut:
1. Sangat sesuai (S1)
: $83-100 \%$
2. Cukup sesuai (S2)
: $50-<83 \%$
3. Sesuai bersyarat (S3)
$: 17-<50 \%$
4. Tidak sesuai (TS)
$:<17 \%$

Kelas S1: Kawasan ini tidak mempunyai pembatas yang serius untuk menarapkan perlakuan yang diberikan atau hanya mempunyai pembatas yang tidak berarti atau tidak berpengaruh nyata terhadap penggunaan dan tidak akan menaikkan masukan atau tingkatan perlakuan yang diberikan.

Kelas S2: Kawasan ini mempunya pembataspembatas yang agak serius untuk mempertahankan tingkat perlakuan yang harus diterapkan. Pembatas ini akan meningkatkan masukan atau tingkat perlakuan yang diberikan.

Kelas S3: Kawasan ini mempunya pembataspembatas yang serius untuk mempertahankan tingkat perlakuan yang 
harus diterapkan. Pembatas akan lebih meningkatkan masukan atau tingkat perlakuan yang diperlukan.

Kelas TS: Kawasan ini mempunyai pembatas permanen, sehingga menghambat segala kemungkinan perlakuan pada daerah tersebut.

\section{HASIL DAN PEMBAHASAN}

Hasil

Tabel 4. Hasil Analisis Matriks Kesesuaian Untuk Wisata Selam.

\begin{tabular}{|c|c|c|c|c|c|c|c|c|c|c|c|c|c|c|}
\hline \multirow{2}{*}{ № } & \multirow{2}{*}{ Parameter } & \multirow{2}{*}{ Bobot } & \multicolumn{3}{|c|}{ st। } & \multicolumn{3}{|c|}{ sтII } & \multicolumn{3}{|c|}{ st III } & \multicolumn{3}{|c|}{ STIV } \\
\hline & & & Hasil & Skor & $\mathrm{Ni}$ & Hasil & Skor & $\mathrm{Ni}$ & Hasil & Skor & $\mathrm{Ni}$ & Hasil & Skor & $\mathrm{Ni}$ \\
\hline 1 & Kecerahan Perairan (\%) & 5 & 82 & 3 & 15 & 82 & 3 & 15 & 84 & 3 & 15 & 89 & 3 & 15 \\
\hline 2 & Tutupan komunitas karang (\%) & 5 & 55.44 & 2 & 10 & 83.52 & 3 & 15 & 17.66 & 0 & 0 & 24.94 & 1 & 5 \\
\hline 3 & Jumlah lifeform karang & 3 & 10 & 2 & 6 & 8 & 2 & 6 & 12 & 3 & و & 17 & 3 & 9 \\
\hline 4 & Jenis Ikan Karang & 3 & 70 & 2 & 6 & 77 & 2 & 6 & 45 & 1 & 3 & 39 & 1 & 3 \\
\hline 5 & Kedalaman terumbu karang $(\mathrm{m})$ & 1 & 10 & 3 & 3 & 10 & 3 & 3 & 10 & 3 & 3 & 10 & 3 & 3 \\
\hline & Kecepatan arus $(\mathrm{cm} / \mathrm{s})$ & 1 & 10 & 3 & 3 & 12 & 3 & 3 & 14 & 3 & 3 & 12 & 3 & 3 \\
\hline \multicolumn{3}{|c|}{ Total } & & & 43 & & & 48 & & & 33 & & & 38 \\
\hline \multicolumn{3}{|c|}{ Indeks Kesesuaian Wisata (\%) } & & & 79.63 & & & 88.89 & & & 61.11 & & & 70.37 \\
\hline \multicolumn{3}{|c|}{ Tingkat Kesesuaian } & & & 52 & & & $\$ 1$ & & & 52 & & & 52 \\
\hline
\end{tabular}

\section{Pembahasan}

Analisis kesesuaian wisata selam dilakukan pada lokasi dengan kedalaman antara 7-10 meter.Tujuan wisata selam salah satunya adalah para wisatawan dapat melihat keindahan bawah laut dari dalam perairan dengan Alat Selam.Parameter yang mendukung dalam penentuan kesesuaian kawasan wisata selam adalah kecerahan perairan, persen tutupan karang, jenis pertumbuhan (lifeform)karang, jenis ikan karang, kecepatan arus dan kedalaman terumbu karang.

Berdasarkan pada matriks kesesuaian wisata selam yang dibuat oleh Yulianda (2007) pada (tabel 3) diatas, Kecerahan perairan merupakan syarat utama yang sangat penting harus dipenuhi dalam kegiatan wisata selam. Semakin cerah suatu perairan maka akan semakin baik untuk mendukung kegiatan wisata selam, karena objek dibawah air akan semakin jelas untuk dilihat. Pentingnya kecerahan merupakan faktor yang mempengaruhi kenyamanan dalam berwisata mengingat kegiatan wisata selam dibatasi oleh air.

Hasil pengukuran kecerahan perairan di kawasan Pantai Dato pada tabel diatas menunjukkan nilai pada setiap Stasiun (I,II,III dan IV) dengan kelas kecerahan $>80 \%$, dimana pada Stasiun I dan V dengan nilai $82 \%$, Stasiun III dengan nilai $84 \%$ dan pada Stasiun IV dengan nilai 89\%. Menurut Yulianda (2007) kecerahan perairan untuk kesesuaian wisata selam dengan nilai $>80 \%$ termasuk dalam kategori sangat sesuai. Dimana kondisi tersebut dapat dikatakan sangat menunjang kenyamanan dalam menikmati keindahan bawah laut, tampa ada gangguan pandangan di bawah air.

Tutupan komunitas karang merupakan salah satu parameter yang sama penting dengan penentuan kecerahan perairan untuk kesesuaian wisata selam. Pada umumnya wisata selam sangat terkait dengan keberadaan ekosistem terumbu karang sebagai objek penyelaman yang menyediakan keindahan organisme laut dan pengalaman baru yang menantang (Yulianda, 2007). Kegiatan wisata selam akan semakin menarik apabila kesehatan karang dalam kondisi baik dan terjaga. Berdasarkan hasil analisis tutupan komunitas karang di kawasan Pantai Dato untuk kesesuaian wisata selam adalah terendah berkisar antara $17,66 \%$ pada Stasiun III, disusul 24,94\% pada Stasiun IV, kemudian 55,44\% pada Stasiun I dan tertinggi $83,50 \%$ pada Stasiun II. Jika berdasarkan kategorinya maka untuk kondisi tutupan komunitas karang termasuk dalam kategori tidak baik pada Stasiun III, kategori kurang baik pada Stasiun IV, kategori baik pada Stasiun I dan kategori sangat baik pada Stasiun II.

Jumlah bentuk pertumbuhan (lifeform) karang pada kawasan perairan Pantai Dato sesuai pengamatan yang dilakukan pada kedalaman yang mendukung kegiatan wisata selam, didapatkan jumlah bentuk pertumbuhan karang tertinggi pada Stasiun I sebanyak 17 jenis, disusul Stasiun III sebanyak 12 jenis, kemudian Stasiun I sebanyak 10 jenis dan yang terendah Stasiun II sebanyak 8 jenis. Hasil tersebut menggambarkan jumlah bentuk pertumbuhan karang di kawasan perairan Pantai Dato untuk kegiatan wisata selam termasuk dalam kategori baik pada Stasiun I dan II, sedangkan pada Stasiun III dan IV termasuk kategori sangat baik.

Selanjutnya parameter jenis ikan karang yang memiliki bobot yang sama dengan jumlah bentuk pertumbuhan karang pada kesesuaian kegiatan wisata selam, didapatkan jenis ikan karang keseluruhan mencapai 231 jenis pada empat stasiun pengamatan kawasan perairan Pantai Dato. Jenis ikan karang yang tertinggi didapatkan pada Stasiun II sebesar 77 jenis, sedangkan terendah didapatkan pada Stasiun IV hanya 39 jenis.Berdasarkan hasil tersebut maka parameter jumlah jenis ikan karang di kawasan perairan Pantai Dato termasuk dalam kategori cukup sesuai dan sesuai bersyarat.

Kecepatan arus untuk kegiatan wisata selam berdasarkan stasiun pengamatan mencapai $14 \mathrm{~cm} / \mathrm{s}$ dan yang terendah $10 \mathrm{~cm} / \mathrm{s}$. Sehingga untuk kawasan perairan Pantai Dato aman untuk dilakukan kegiatan wisata selam. Sedangkan jika melihat nilai kecepatan arus pada stasiun pengamatan ekologi karang, maka 
kategori untuk mendukung kegiatan wisata selam termasuk sangat baik karena nilai kecepatan arus pada titik pengamatan ekologi karang tidak ada yang melebihi $15 \mathrm{~cm} / \mathrm{s}$. Parameter terakhir yang mendukung kegiatan wisata selam adalah kedalaman terumbu karang. Seperti yang telah didapatkan kedalaman terumbu karang mencapai 13 meter, kedalaman tersebut tergolong dalam kategori sangat sesuai untuk mendukung kegiatan wisata selam.

Berdasarkan hasil analisis matriks kesesuaian kawasan wisata selam yang disajikan pada (Tabel 16) bahwa pada Stasiun II termasuk kategori S1 (sangat sesuai) untuk kegiatan wisata selam (diving) namun masih ada parameter yang memiliki nilai dibawah standar kesesuaian kawasan untuk kategori S1 yakni pada parameter jumlah lifeform karang dan jenis ikan karang.Sedangkan Stasiun I, III dan IV termasuk kategori S2 (cukup sesuai) yang berarti masih ada beberapa faktor bagi kesesuaian wisata tersebut yang masih minim dan menjadi faktor pembatas bagi kesesuaian kawasan untuk dijadikan kawasan wisata. Faktor yang masih minim dan menjadi faktor pembatas pada ketiga stasiun tersebut yakni parameter tutupan karang, jumlah lifeform karang dan jenis ikan karang.

Lokasi yang direkomendasikan untuk kegiatan wisata selam dapat dilakukan pada daerah tubir di setiap Stasiun, namun spot yang paling direkomendasikan yakni pada Stasiun II dimana pada Stasiun ini memiliki kondisi karang yang sangat baik dan diperoleh jenis ikan karang tertinggi yang merupakan parameter penting dalam penunjang kepuasan tersendiri bagi pengunjung. Hal ini didukung oleh Bayuadi dkk., (2013) bahwa yang paling berpengaruh terhadap peningkatan kepuasan pengunjung adalah jenis ikan karang, ukuran karang dan banyaknya jenis karang. Namun, lokasi penyelaman ini harus di kelola dan dijaga dengan baik oleh pengelola maupun penyelam agar tidak merusak terumbu karang yang ada, hal ini didukung oleh pernyataan Tratalos dan Austin (2001) dalam Bayuadi dkk., (2013) bahwa kegiatan penyelaman memberikan dampak yang signifikan terhadap area yang menjadi daerah penyelaman, dimana penutupan karang keras dan karang lunak menjadi menurun serta banyak ditemukan patahan karang dan karang mati, sehingga perlu adanya pengelolaan yang lebih baik terhadap kegiatan penyelaman di daerah yang menjadi spot penyelaman.

\section{KESIMPULAN DAN SARAN \\ Kesimpulan}

Dari faktor internal dapat disimpulkan faktor kekuatan adalah 2,35 lebih besar dibandingkan faktor kelemahan adalah 1,45 hal ini menunjukkan bahwa faktor kekuatan dapat mendukung pengembangan usaha pemasaran ikan kakap merah di KUB (Kelompok Usaha Bersama) Kayra Mina Lestari sedangkan untuk faktor eksternal dapat disimpukan nilai faktor peluang adalah 2,1 lebih besar dari nilai total faktor ancaman 0,80 hal ini menunjukkan bahwa Kelompo Usaha Bersama Karya Mina Lestari memiliki potensi peluang yang besar.

\section{DAFTAR PUSTAKA}

Armos, N. H. 2013. Studi Kesesuaian Lahan Pantai Wisata Boe Desa Mappakalompo Kecamatan Galesong Ditinjau Berdasarkan Biogeofisik. Skripsi. Jurusan Ilmu Kelautan. Universitas Hasanuddin. Makassar.

Bayuadi, A., A. Mustafa dan R. Ketjulan. 2013. Kajian Potensi Kawasan dan Kesesuaian Ekosistem Terumbu Karang di Pulau Lara Untuk Pengembangan Ekowisata Bahari. Jurnal Mina Laut Indonesia.UNHALU.Kendari.

Dahuri, R., J. Rais, S. P. Ginting dan M. J. Sitepu. 2004. Pengelolaan Sumber Daya Wilayah Pesisir dan Lautan Secara Terpadu. Pradnya Paramita. Jakarta.

English, S.C., Wilkinson, V., Baker, 1997. Survey Manual for Tropical Marine Resources. ASEAN-Australian Marina Science Project: Living Coastal Resources. Australian Institute of Marine Science, Townsville. Australia. 390 hal.

Rapy I. 2003. Analisis Keberlanjutan Lahan Budidaya Rumput Laut Di Teluk Puntondo Kabupaten Takalar. Skripsi Jurusan Ilmu Kelautan. Universitas Hasanuddin. Makassar.

Yulianda F. 2007. Ekowisata Bahari Sebagai Alternatif Pemanfaatan Sumberdaya Pesisir Berbasis Konservasi. Standar Sains Departemen Manajemen Sumberdaya Perairan. Fakultas Perikanan dan Ilmu Kelautan.Institut Pertanian Bogor. Bogor. 
Yusri, S., 2009. Pemantauan Ekosistem Pesisir Di Kepulauan Seribu. www.Terangi.or.id. Diakses pada tanggal 08 Juli 2015 pukul 15 : 00 wita 